\title{
ANALYSIS OF MATERNAL MORTALITY DETERMINANTS IN BONDOWOSO DISTRICT, EAST JAVA
}

\author{
Ratna Diana Fransiska1), Supriyadi Hari Respati²), Ambar Mudigdo3) \\ ${ }^{1)}$ Masters Program in Public Health, Sebelas Maret University \\ 2)Department of Obstetrics and Gynecology, RSUD Dr. Moewardi, Surakarta \\ 3)Department of Anatomical Pathology, Faculty of Medicine, Sebelas \\ Maret University
}

\begin{abstract}
Background: Data from Population Inter-Census Survey (Survei Penduduk Antar Sensus, SUPAS) 2015 showed that maternal mortality ratio was 305 per 100,000 live-births in Indonesia. Sustainable Development Goals (SDGs) set 70 per 100,000 live-births as the target for maternal mortality ratio to be achived by 2030. This study aimed to analyze the determinants of maternal mortality in Bondowoso district, East Java.

Subjects and Method: This was an analytic observational study with casecontrol design. This study was carried out at 17 Community Health Centers, in Bondowoso, East Java from February to March 2017. A sample of 117 study subjects, consisting of 39 cases of maternal death and 78 control, was selected for this study by fixed disease sampling. The dependent variable was incidence of maternal death. The independent variables were maternal education, maternal employment status, antenatal care visit, complication, late model, and other pregnancy risk factors. The data were collected from the obstetric and medical record, as well as a set of questionnaire. The data were analyzed by path analysis

Results: Determinants of maternal death included late decision making ( $b=$ 2.37; $95 \% \mathrm{CI}=0.81$ to $3.93 ; \mathrm{p}=0.003)$, late transfer to the hospital $(\mathrm{b}=2.35$; $95 \% \mathrm{CI}=-0.21$ to 4.91 ; to $\mathrm{p}=0.072)$, late handling at the hospital $(\mathrm{b}=2.36$; $95 \% \mathrm{CI}=-0.19$ to $4.91 ; \mathrm{p}=0.069)$, and complication $(\mathrm{b}=2.5 ; 95 \% \mathrm{CI}=1.41$ to $3.62 ; \mathrm{p}<0.001)$. Complication was determined by completeness of antenatal visits $(b=-1.01 ; 95 \% \mathrm{CI}=-1.94$ to $-0.09 ; \mathrm{p}=0.032)$, and existence of pregnancy risk factor $(b=1.90 ; 95 \% \mathrm{CI}=1.01$ to $2.78 ; \mathrm{p}=<0.001)$. Pregnancy risk factors was determined by completeness of antenatal visit $(b=-1.09 ; 95 \%$ $\mathrm{CI}=-1.99$ to $-0.19 ; \mathrm{p}=0.018)$, maternal education $(\mathrm{b}=-0.47 ; 95 \% \mathrm{CI}=-0.85$ to -0.07; $\mathrm{p}=0.020)$, and maternal employment status $(\mathrm{b}=0.14 ; 95 \% \mathrm{CI}=-0.17$ to $0.45 ; \mathrm{p}=0.369)$. Antenatal visit was determined by maternal education $(\mathrm{b}=$ $0.54 ; 95 \% \mathrm{CI}=0.10$ to $0.99 ; \mathrm{p}=0.017)$ and maternal employment status $(\mathrm{b}=$ $0.08 ; 95 \% \mathrm{CI}=-0.29$ to $0.45 ; \mathrm{p}=0.683$ ).

Conclusion: The direct determinants of maternal death include late decision making, late transfer to the hospital, late handling at the hospital, and complication. The indirect determinants of maternal death include completeness of antenatal visits, existence of pregnancy risk factor, maternal education, and maternal employment status.
\end{abstract}

Keywords: determinant, delay, complication, antenatal care, maternal death

Correspondence: Ratna Diana Fransiska. Masters Program in Public Health, Sebelas Maret University, Jl. Ir. Sutami 36 A, Surakarta 57126, Central Java, Indonesia. Email: ratnadianaoo@gmail.com.

Mobile: +6285778822668 . 